\title{
Structural Analysis of Strategic Variables through MICMAC Use: Case Study
}

Martha Benjumea-Arias

\author{
Professor of Administrative Sciences, Instituto Tecnológico Metropolitano (Colombia) \\ Email: marthabenjumea@itm.edu.co

\section{Leonel Castañeda}

Professor of Administrative Sciences, Instituto Tecnológico Metropolitano (Colombia)

Email: leonelcastaneda@itm.edu.co

\author{
Alejandro Valencia-Arias \\ Professor of Administrative Sciences, Instituto Tecnológico Metropolitano (Colombia) \\ Corresponding Author Email: jhoanyvalencia@itm.edu.co
}

\section{Doi:10.5901/mjss.2016.v7n4p}

\section{Abstract}

The technique of structural analysis in foresight study from the Faculty of Economic and Administrative Sciences of Instituto Tecnológico Metropolitano- ITM Medellin, Colombia allowed defining the strategic variables that will guide its strengthening in 2020. The aim of this article is to present the conceptual references of the technique and results of the implementation of MICMAC to determine the degree of influence and dependence variables. The methodology used to achieve the objective was the analysis of 55 key variables that were prioritized because of their importance to determine the 15 strategic variables that have to project the future actions taking into account the situation of autonomy, power, conflict and output. In this regard, it is concluded on the relevance of the variables in the power quadrant corresponding to the mobility, physical and technological infrastructure as they are those that enable participation and interaction with other academic, productive and governmental entities; and in the quadrant of link variables of strategic direction, teachers, students, research, partnerships, academic management, financial resources and innovation have the greatest influence on future variables that have an effect on capacity building and the effective allocation of institutional resources.

Keywords: strategic foresight, education, higher education institutions, future, strategic variable

\section{Introduction}

The dynamics of the labor market and social needs faced by Higher Education Institutions leads to the need of permanent research on technological, scientific, educational and social trends of regional and national context. This is in order to identify clear paths of development, strengthening and positioning of these institutions in society (Noguera and Cubillos, 2007). Thus, identification of trends of change factors in the Faculty of Economics and Administrative Sciences Instituto Tecnológico Metropolitano, a Higher Education Institution attached to the Mayoralty of Medellin, Colombia; helps to provide references in the scientific field, necessary for capacity building to provide it with a supply of knowledge-based innovation and technological development of its products, processes and services. That is, factors of change in the scientific field that respond to the needs and opportunities that are set out by changes in local, regional, national and international environment (Valderrama, 2005; Muñoz-Cano, Córdoba and Priego, 2012), and contribute to problem solving and social needs in the contexts that universities are involved (Parra, 2004).

The impact on education field and specifically in higher education, it sets out the need of facing changes that allow creating operational and dynamic capabilities (Grant, 2006) in the incorporation of teaching and research processes knowledge. In this part, appear new studies to orientate the programs and management processes, where the quality and competiveness factors in higher education play a relevant role in the institutional recognition. Some oriented studies are involved in: foresight analysis of management department of Colegio Mayor de Nuestra Señora del Rosario (Ochoa and Orjuela, 2012) and design of a foresight methodology applied to higher education (Parra et al., 2007); current tendencies in higher education as: world and country tendencies (Restrepo, 2006), study of academic foresight of agro-industrial department of the Universidad Pontificia Bolivariana at 2020 year (Zartha and Orozco, 2008), current situation and sub- 
academic programs foresight of the Universidad Nacional Abierta (Gutiérrez, 2007), the role of foresight action in Venezuelan higher education: Risks and challenges to think the university of tomorrow (Villalobos, 2003), and the application of foresight methods in the determination of distinctive competences in Cimex de Cienfuegos branch (Hernández and Rodríguez, 2011).

The objects of knowledge of the Faculty are the disciplinary compendiums of economics and management sciences. The thematic areas currently served are: quality and metrology; production, cost accounting, budgeting systems, finance and financial affairs, administrative management (business) and technology management (technology management and innovation) and entrepreneurship.

In this sense, it is a mechanism that responds to the social and productive sectors, and enables the creation of new academic activities and strengthening of existing ones. Foresight studies are necessary, as they allow addressing the Faculty programs. For this purpose, the techniques used in the foresight study are not restricted to quantitative methods; they also use qualitative methods and they are systemically combined (Rodríguez, 2012; Pereda, 1992; Riffo, 1997). This facilitates the identification of strategic key variables and emerging events, product of the potential behavior by the agents that could alter the normal course of trends.

\section{Theoretical Framework}

Foresight studies have their theoretical basis on the approach of the French school, and strategic foresight whose greatest exponents are and Michel Godet (1999), Gaston Berger (2003) and Hugues de Jouvenel (2011). Identifying changes and orientation programs implies that it should be viewed under complementary methods and evolutionary trajectories, i.e. "the belief in the occurrence of a unique perceptible future at first observation is displaced by the practice of monitoring, continuous analysis and development of possible scenarios" (Godet, 1999).

Foresight planning seeks to provide educational responses to the need to collect, integrate and relate relevant information, using tools that allow for analysis of strategic or key variables, behavior and forces of social actors, the building of bet scenario and strategies to reach it (Apodaca, 2001; Georghiou et al., 2012).

This process involves formulating a series of questions that lead to identify the elements to shape the future. These key questions are: What are the key or strategic variables that define the organization now? In which scenarios could we find the organization, years later? Which of these is the most convenient? What strategies are necessary to implement for the best future option and to avoid those that do not? (Mojica, 2005). These are harmoniously combined to offer alternative scenarios: where we go? Its strategic evaluation: Where is convenient to go? Its tactical planning: How, where, with what, with who? (Miklos and Tello, 2007)

The formulation of these questions has a purpose, it seeks to respond in a systematic way without leaving out the management of uncertainty that involves the search for a possible future. For that effect could be considered in the proposal of how to carry out processes to identify a possible futures (Mojica, 2008; Godet, 1999; Jouvenel and Medina, 2011).

- State of the art about processes work on the topic: indicators and measurements of phenomena.

- Trends, change factors and characteristics of the company and the environment.

- Strategic or key variables: the foresight exercise requires knowledge of the subject variables being studied. General explorations of the phenomena that define the subject take place, to point out the strategic variables or fundamental aspects of the topic that are being analyzed.

- Behaviors of social actors: analyzes the strengths of the actors; convergences and divergences (alliances and conflicts) that can exist for achieving goals.

- Probable scenario and alternative scenarios and bet scenario: A scenario is a picture of the future, usually several types of images or future scenarios are identified.

To develop the stages, the using of foresight tools is proposed: Regnier's abacus, structural method (MICMAC), the method of play of actors (MACTOR), DELPHI technique, and scenario analysis to evaluate the probability of events (SMIC). For the development of this article, one of the techniques used in the study foresight in the Faculty is analyzed, which corresponds to the structural analysis method by applying the MICMAC.

\subsection{Importance of strutural analysis}

Structural analysis is a technique used to identify key variables which can be described processes of collective reflection to build the vision of the future (Ambrosio and Delgado 2008). As a result, the method reveals the "structure" of relations 
of dependence and mobility between system variables and points out the essential variables in the evolution of the system (Ambrosio and Delgado, 2008). Finally, the method determines which of these variables are the most important and then identifies the main actors that can affect the object of study (Guzmán, Malaver, and Rivera, 2009)

The variables are chosen by experts, who also determine the direct relations between them, and using mathematics, the indirect variables are determined. This process can be done through "brainstorming" experts (Portillo and Ortega, 2004). In this regard, the influence of one variable on another can be classified into direct, indirect and potential. These influences are described after the key variables are identified. The influence is direct if a variable $A$ has an effect on another variable $B$ and indirect, if the variable $A$ influences $B$ and $B$ influences a third variable $C$. Thus, by transitivity, $C$ is indirectly influenced by $A$. The potential influence has to do with the influence that should have a variable A over another $B$, and if there is no direct influence of one variable on another, it is said that there is no influence (Portillo and Ortega, 2004).

Applying the properties of the Markov chain, this tool allows establishing hierarchies and classifications of the elements according to their dependency and mobility properties. The successive power of matrix $2,3,4 \ldots \mathrm{n}$ powers leads to a classification of the different elements of the matrix according to the total number of conducted or received influences (Ambrosio and Delgado, 2008).

The method of structural analysis can be very useful as a support in decision-making, evaluation of alternative future, operational planning and in determining the impact of strategies or areas of research in the study of a discipline (Morin and Pakman, 1994).

\subsection{MICMAC application}

The Micmac software has been developed by the Institut d'Innovation Informatique pour l'Entreprise, under the supervision of their creators, Laboratory for investigation in Prospective Strategy and Organization, LIPSOR (Godet, 1999). This corresponds to the structural analysis where the structure is defined as a reality that is studied as a system, and these elements keep interdependencies (Mojica, 2005), at the same time it allows the consideration of qualitative variables and exploring multiple and uncertain futures (Jimenez, 2009).

The method starts from the problem definition, then a list of internal and external variables are identified. It proceeds to analyze the relationship between the variables that system is made, weighing that relationship according to the degree of mobility and dependence between existed variables. These variables are weighted according to the following qualification: if the degree of influence is non-existent, low, medium or high, a scale that can be $0,1,2$, and 3 or $0,1,3$ and 5 is used. This matrix entry is generally qualitative, so it is possible to adjust the intensities of the relationships $(0=$ non-existent, $1=$ weak, $2=$ medium, $3=$ strong, $P=$ potential $)$. The qualifying result identifies the key variables: direct and indirect classification.

Analysis of mobility (Influence) and dependence are obtained by the location of the indicator of the variable in the quadrant, resulting in a variable that can be power variable, autonomous, of conflict or output variable, according to their degree of influence and dependence.

\section{Methodology}

The methodological bases that guide the foresight study of the Faculty of Economics and Administrative Sciences are analyzed from the trends and change factors for the future of the programs. For this purpose, the academic context and programs are analyzed. This information is contained in educational projects programs-EPP-, which is complemented by a review of other foresight studies in Higher Education Institutions (Gutiérrez, 2012), in which a marked exploratory and normative approach are stood out. This search has focused on the processes of accreditation, mobility, research, relationship with the productive sector, interdisciplinary training, profiles of teachers and students, recognition and visibility of programs in the community, inter-institutionality, knowledge transfer, and others.

\section{Analysis of results}

In the first phase of the process, preliminary results of the study in which a literature review on prospective studies in the national and international level that allowed realizing the theoretical, conceptual and methodological approach are presented. Subsequently, Educational Projects Programs "EPP" were reviewed and 59 variables that were rated by the leading team by using the Regnier's abacus were proposed. Subsequently, an analysis is carried out on the impact that each variable would have on the development of the Faculty, facilitating about 15 key or strategic variables as shown 
below:

Delimitation and grouping of variables enables distinguishing those that are key or critical for success. Consequently, these are the variables that can be influenced through decisions made and orientate the Faculty policies. In the same way, they can significantly affect the competitive position of the programs (see Table 1).

Table 1: Rating of strategic variables' matrix

\begin{tabular}{|c|c|c|c|c|c|c|c|c|c|c|c|c|c|c|c|}
\hline & $\begin{array}{c}1: \\
\text { MOV }\end{array}$ & $\begin{array}{l}2: \\
\text { INV }\end{array}$ & $\begin{array}{c}3: \\
\text { PRO } \\
\text { ACA }\end{array}$ & $\begin{array}{c}4: \\
\text { EXT }\end{array}$ & $\begin{array}{c}5: \\
\text { DIR } \\
\text { EST }\end{array}$ & $\begin{array}{l}6: \text { INF } \\
\text { FIS-TE }\end{array}$ & $\begin{array}{c}\text { 7: } \\
\text { PROY } \\
\text { PRG }\end{array}$ & $\begin{array}{l}\text { 8: } \\
\text { VIR }\end{array}$ & $\begin{array}{c}9: \\
\text { PROY } \\
\text { SOC }\end{array}$ & $\begin{array}{l}10: \\
\text { DOC }\end{array}$ & $\begin{array}{l}\text { 11: } \\
\text { EGR }\end{array}$ & $\begin{array}{l}12: \\
\text { EST }\end{array}$ & $\begin{array}{c}\text { 13: } \\
\text { ALIAN }\end{array}$ & $\begin{array}{c}14: \\
\text { REC } \\
\text { FIN }\end{array}$ & $\begin{array}{l}15: \\
\text { INN - } \\
\text { CON }\end{array}$ \\
\hline $1: \mathrm{MOV}$ & 0 & 3 & 2 & 2 & 2 & 1 & 3 & 1 & 2 & 3 & 2 & 3 & 3 & 2 & 3 \\
\hline $2:$ INV & 3 & 0 & 3 & 2 & 3 & 2 & 3 & 1 & 2 & 3 & 2 & 3 & 3 & 2 & 3 \\
\hline $\begin{array}{c}3: \text { PRO } \\
\text { ACA }\end{array}$ & 2 & 3 & 0 & 2 & 2 & 1 & 3 & 2 & 2 & 3 & 2 & 2 & 2 & 2 & 2 \\
\hline $4:$ EXT & 2 & 2 & 1 & 0 & 2 & 2 & 2 & 2 & 3 & 2 & 2 & 2 & 3 & 3 & 2 \\
\hline $\begin{array}{c}5: \text { DIR } \\
\text { EST }\end{array}$ & 2 & 3 & 3 & 2 & 0 & 3 & 3 & 3 & 3 & 3 & 3 & 3 & 3 & 3 & 3 \\
\hline $\begin{array}{l}\text { 6: INF } \\
\text { FIS-TE }\end{array}$ & 1 & 2 & 2 & 2 & 2 & 0 & 2 & 2 & 2 & 3 & 2 & 3 & 2 & 3 & 3 \\
\hline $\begin{array}{c}7: \\
\text { PROY } \\
\text { PRG }\end{array}$ & 2 & 3 & 3 & 3 & 3 & 2 & 0 & 3 & 3 & 3 & 3 & 3 & 2 & 3 & 3 \\
\hline $8: \mathrm{VIR}$ & 1 & 2 & 2 & 2 & 2 & 2 & 2 & 0 & 2 & 3 & 2 & 2 & 2 & 2 & 2 \\
\hline $\begin{array}{c}: \\
\text { PROY } \\
\text { SOC }\end{array}$ & 1 & 2 & 2 & 2 & 2 & 2 & 2 & 2 & 0 & 3 & 2 & 3 & 2 & 3 & 2 \\
\hline $\begin{array}{l}\text { 10: } \\
\text { DOC }\end{array}$ & 3 & 3 & 3 & 2 & 3 & 2 & 3 & 3 & 2 & 0 & 2 & 3 & 3 & 2 & 3 \\
\hline $\begin{array}{l}\text { 11: } \\
\text { EGR }\end{array}$ & 1 & 1 & 1 & 2 & 2 & 1 & 2 & 2 & 2 & 1 & 0 & 1 & 2 & 2 & 2 \\
\hline 12: EST & 3 & 3 & 2 & 2 & 2 & 2 & 3 & 3 & 3 & 3 & 1 & 0 & 2 & 2 & 2 \\
\hline $\begin{array}{c}13: \\
\text { ALIAN }\end{array}$ & 3 & 3 & 3 & 3 & 3 & 2 & 3 & 2 & 3 & 3 & 2 & 3 & 0 & 3 & 3 \\
\hline $\begin{array}{c}14: \\
\text { REC FIN }\end{array}$ & 3 & 3 & 3 & 2 & 3 & 3 & 3 & 2 & 2 & 3 & 2 & 3 & 3 & 0 & 3 \\
\hline $\begin{array}{c}15: \text { INN } \\
- \text { CON }\end{array}$ & 3 & 3 & 3 & 2 & 3 & 3 & 3 & 2 & 2 & 3 & 2 & 3 & 3 & 3 & 0 \\
\hline
\end{tabular}

These variables are explained as following:

Mobility (MOV): enables the different actors (teachers, students, graduates, administration staff, etc.) participation and interaction with other higher education institutions and the productive sector in exchange, internships, joint projects, and others.

Research (INV): development, management, marketing and recognition of research projects.

Academic production (PRO ACA): any material that can be developed as a result of teaching practice (modules, courses, guides, training materials, etc.).

Extension (EXT): offer of update courses, seminars, conferences, programs, projects, and others; which enable different audience's qualification.

Institutional strategic direction (DIR EST): responds to the institutional philosophy, policies, development plan, strategic lines, corporate welfare, evaluation and accreditation.

Physical and technological infrastructure (INF FIS-TE): represents the logistics support that enables the realization and development of academic activity.

Future projection of programs and academic management (PROY PRG): Design and relevance of curriculum development and program development, standardization, curricular flexibility, curriculum, regionalization, distance modalities and plurilingualism.

Virtuality (VIR): offering academic activities from using virtual media (use of ICTs).

Social projection (PROY SOC): professional practice activities (social - business), consulting, consultancy and strengthening of the sector.

Teaching $(D O C)$ : teaching and learning methodologies, linking processes, recruitment, qualifications, updating, scale and performance evaluation. 
Graduates (EGR): information system, professional relations and job performance, academic continuity, updating cruses and association.

Students (EST): admission process, requirements and quality of student retention, academic and social support, participation in various academic institutions, and others.

Business alliances, agreements, and membership networks (ALIAN): articulation of programs of the Faculty with other institutions and organizations at national and international level. of incomes.

Generating financial resources and growth (REC END): creating products and services that enable the production

Innovation and knowledge transfer (INN CON): mechanisms to create, develop and explain knowledge.

Table 2: Explanation of the quadrants.

\begin{tabular}{|l|l|l|l|l|}
\hline Situation & \multicolumn{2}{|l|}{ Name } & Description \\
\hline Autonomous & I & Excluded & $\begin{array}{l}\text { No significant influence over the other or not influenced by them, since they have little } \\
\text { mobility and little dependence. }\end{array}$ \\
\hline Power & II & Input & They have the highest mobility and lower dependence. \\
\hline Conflict & III & Liaison & $\begin{array}{l}\text { They have high mobility and high dependency. These very influential variables are highly } \\
\text { vulnerable, influence over the remaining, yet influenced by them. }\end{array}$ \\
\hline Output & IV & Result & They are the result of the above, have low mobility but high dependence. \\
\hline
\end{tabular}

Source: Adapted from Godet (1999).

The following quadrants are presented in figure 1:

- Lower left quadrant; "autonomous" or "Excluded": extension variables, virtuality, graduates, academic programs and social projection. No significant influence over the other or not influenced by them, since they have little mobility and little dependence.

- Upper left quadrant; "Input" or "Power": the variables of mobility and physical and technological infrastructure, have the highest influence and lower dependence. These variables are very important for the results obtained from the problem of the future of the Faculty, because they have influence on most of them and have little dependence of them; any change that occur in them will have repercussions throughout the system.

- Upper right quadrant; "Liaison" or "conflict": strategic direction variables, teachers, students, research, partnerships, projects and programs, financial resources, innovation and knowledge transfer. They have high influence and high dependency, which means they are very influential and highly vulnerable variables, as any variation of them has an influence on the remaining, and the outputs or results.

- Lower right quadrant; "Result": the study provides no variables in that quadrant. It describes the variables that have little influence and high dependence.

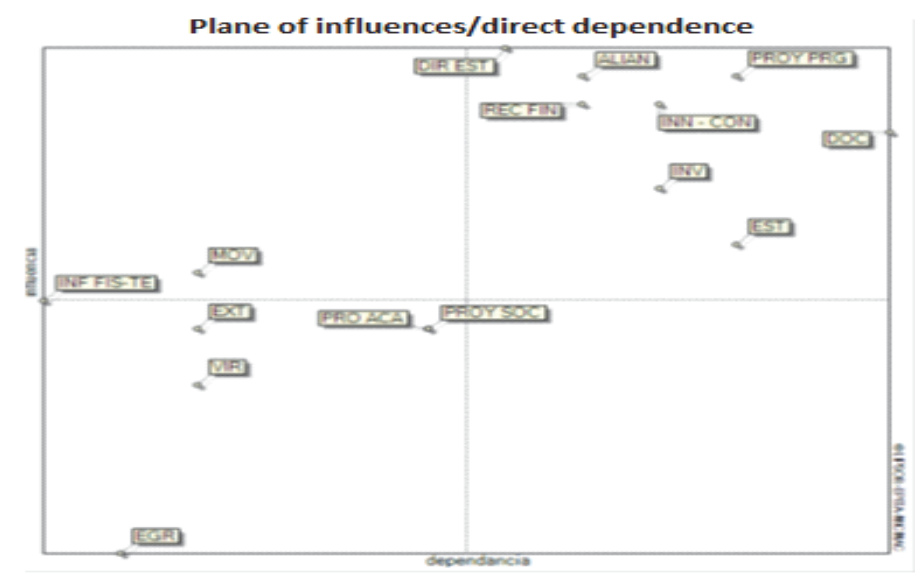

Figure 1: Plane of direct influences. 
Figure 1 shows how the variables located in Quadrant Power, have a high influence on the future of the Faculty, as it has greater mobility to generate future system-width and low dependence of other variables. These variables largely define the future of the Faculty and influence others in the future generation. The first of them is Mobility (MOV), which enables participation and interaction with other academic, productive and government entities. The second one is the physical and technological infrastructure (INF FIS-TE) which provides logistic support for the implementation and development of the academic function of the Faculty, this future variable, has been at the boundary between the variables of Power and the autonomous variables, indicating that it requires greater management to ensure that their attributes are subsequently enhanced.

The second most important quadrant is Conflict Quadrant, where most of the critical variables for the future were located. In order mobility, it was verified that there, the Institutional Strategic Direction (DIR EST) variable assume greater relevance in the quadrant, as it has the greatest influence on other future variables. This variable contains within itself the institutional philosophy, policies and strategic guidelines of Instituto Tecnológico Metropolitano, under which the Faculty of Economics and Administrative Sciences is guided and serves to establish the north in their daily work. It happens there in the short-term management but it will be vital in the near future of the Faculty.

In this same quadrant and a second level of importance, there are the variables of Business alliances, agreements, and membership networks (ALIAN), and then the Future projection of programs and academic management (PROY $P R G$ ). These variables refer in the first instance to the ability of the Faculty to generate dynamic of team working, both at mission and vision level, with other institutions in the international and national level, to enable it to enhance its strategic proposals, as well as to ensure that the Faculty achieves its objectives and goals, it can succeed significantly in higher levels. Respectively, academic management is the variable which aims for the welfare of the current level program curriculum, social relevance, academic flexibility, teaching-learning models in accordance with the disciplines it teaches.

In the analysis, and a relevant third momentum in this quadrant, is financial resources and economic growth (REC END) of the Faculty and the Innovation and Knowledge Transfer (INN CON). In these variables we analyzed the way that products and services that enhance revenue generation are created, along with the mechanisms and ways to promote the creation and development of knowledge, impacting both production and business organizations, as well as social organizations of the city and the region. These variables energize the Faculty in its budget areas and will print a catalyst seal of future in the fields of technology management, besides aiming to improve productivity and competitiveness of regional businesses.

Finally, quadrants appear in order of importance in generating future, Teaching (DOC), Research (INV), Students $(E S T)$, relevant elements in the mission of the Faculty in the training model of ITM in recent years and which aims at being the leading guide for the coming years.

The teaching- learning methodology and recruitment and qualification processes are the most relevant in the future of teachers, who will be responsible for the transmission of relevant knowledge and current affairs on Management and Technology. They will be relevant part in the research, which is a future aim as well as the management of research projects in all its dimensions and scope.

Student as formation aim for the Faculty, it is evident in the future of Faculty, from admission, stay and completion of professional education, as well as the participation of other academic institutions that verify its participation competence of institutional governance.

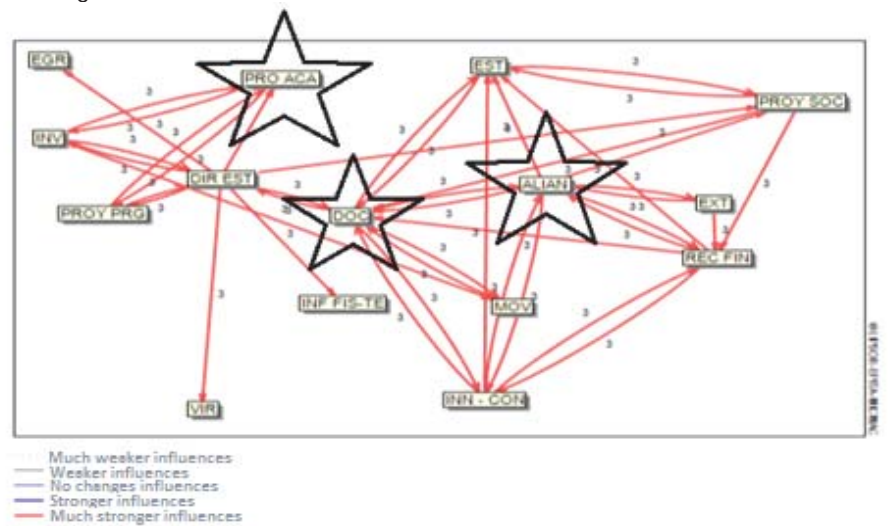

Figure 2: Direct influences. 
Figure 2 shows the variables with much stronger influences over other variables that are subordinate: the strategic direction has the ability to influence the Future projection of programs and academic management, research, virtuality and teachers. Teachers, in turn, have a direct influence on students, social projection, mobility and innovation and knowledge transfer. Finally, the variable of strategic alliances facilitates the development of the extension, the generation of financial resources, the projection of teachers in the middle and the development of innovation and knowledge transfer.

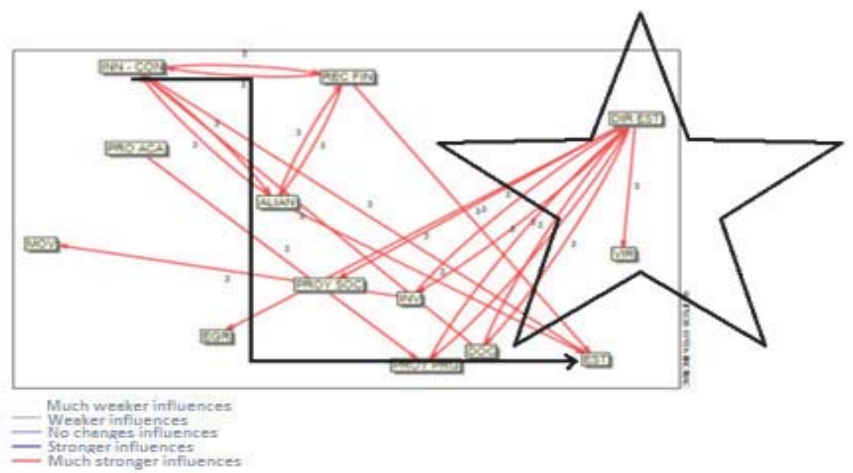

Figure 3: Potential direct influences.

Likewise, Figure 3 traces the strength that the Innovation and knowledge transfer variables will have in the future, Business alliances, agreements, and membership networks and management students to enable the generation of financial resources. In the management benchmark, the variable Strategic Direction should focus primarily on invigorating the management with teachers, projection, creation of new programs and research.

Figure of Potential indirect influences

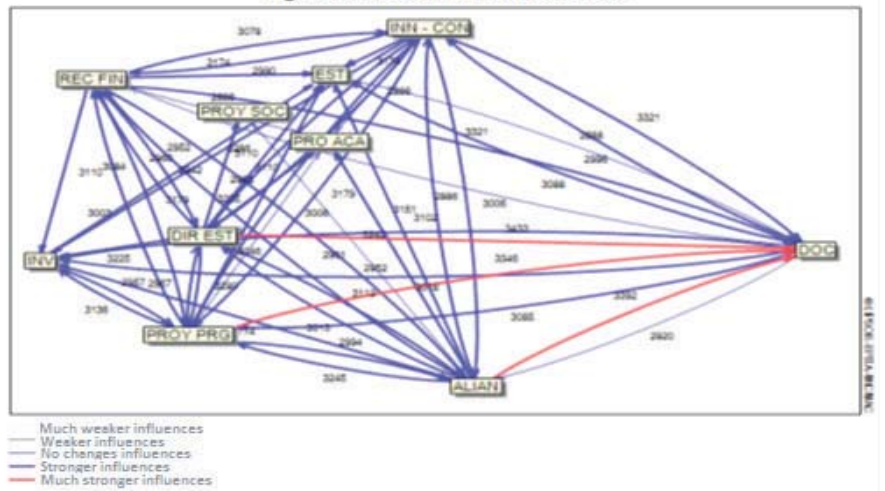

Figure 4: Potential indirect influences.

Similarly to the direct influences, indirect analysis (Figure 4) Teaching variable can have a potential influence on the strategic direction (Fondón, Madero and Sarmiento, 2010), and the future projection of programs and partnerships.

\section{Conclusions}

The foresight part from the fact that not only is it feasibly intelligent to know the future, but it is also possible to conceive alternative futures and select the best to build it strategically. In this sense, the development of the foresight study of the Faculty of Economics and Administrative Sciences of the Instituto Tecnológico Metropolitano analyzes the critical 
success factors and characteristics. These are part of the new trends in higher education, where the internationalization and mobility, competitiveness and positioning of the organization that enables more dynamic attracting new talent (teachers and researchers) are highlighting.

On the other hand, the quality and orientation to excellence with a variety of undergraduate and graduate programs; cooperation and inter-institutional relations as a facilitator of the incorporation of scientific knowledge by way of research (Palomo, Veloso and Schmal, 2007). The integral education -oriented towards developing abilities that really allow meeting the needs of the productive sector, and finally, the orientation of service to stakeholders as a strategy to ensure greater coverage and sustainability of academic offerings and services.

In determining key variables that affect capacity creation and the effective allocation of resources are the variables of power that have a high influence on the future of the Faculty (Mobility), the critical variables for the future (Strategic Direction), given that decisions are taken in the short term it will be vital in the near future of the Faculty. In this vein, and a second level of importance, are the variables of Business Alliances, Agreements, Networks and Memberships and Future projection programs "Academic Management". These variables refer to the ability of the faculty to generate dynamic of working together, both at mission and vision, with other institutions in the national and international order, to enable it to enhance its strategic proposals, as a guarantee to achieve its objectives and goals, which can exceed significantly higher levels.

In the analysis and relevant third momentum in this quadrant, Financial Resources and Economic Growth at the Faculty are, by the Innovation and Knowledge Transfer. Finally, they appear in the quadrant, in order of importance in generating future, Teaching, Research and Students, relevant elements of the mission of the Faculty, and in the training model of ITM in recent years and which aims to be the leading guide for the next years. In this regard it is important to establish policies on admission, stay and completion of professional education, as well as the participation of other academic institutions that verify their participation competence of institutional governance.

The teaching- learning methodology and recruitment and qualification processes are the most relevant in the future of teachers, who will be responsible for the transmission of relevant knowledge and current affairs on Management and Technology. They will be relevant part in the research, which is a future aim; the management of research projects in all their dimensions and scope.

The various forward techniques can elucidate a broad overview of actions that the Faculty should undertake to take the future from the condition of the unpredictable, besides academic transformations for social and economic development of stakeholders (Community and productive sector). At 2020, the Faculty should guide flexible models characterized by a strong focus on linking networks of knowledge, flexibility and relevance of curricula, education focused on the quality whose dynamic axis are meaningful learning with a strong practical guidance to the development and management of ICT.

The objective of structural analysis using the MICMAC technique is to discover the components of a system related to its direct and indirect influences, to understand these relations, and identify the strategic variables to reduce system complexity. On the other hand, it can be helpful to consider the future of evaluating strategic decisions. In relation to this technique, it can derive on studies in other academic and administrative instances that allows to efficiently orientate the missional programs of teaching, social projection and investigation, in order to respond to new challenges such as the transformation of the academic processes to face the post-conflict, the students well-being in opposition to the psychsocial issues and addict behaviors, university start-ups struggling with firms' market power, and training processes oriented towards a multicultural profile of future graduates.

Finally, increasing the way of internationalization of education and knowledge management through increased standards of oriented research directed to solve the local and regional problems, which constitute permanent challenges of training students, teachers and administrative staff.

\section{References}

Ambrosio-Albala, M., \& Delgado, M. (2008, August). Understanding rural areas dynamics from a complex perspective. An application of Prospective Structural Analysis. In 12th Congress of the European Association of Agrarian Economists (EAAE), Ghent, Belgium.

Apodaca, P. (2001). Calidad y evaluación de la educación superior: situación actual y prospective [Quality and evaluation of higher education: current and prospective situation]. Revista de Investigación Educativa, 19(2), 367-382.

Berger, G. (2003). La actitud prospectiva [The prospective attitude]. Revista Universidad de Guadalajara, 26, 33-36.

Jouvenel, H., \& Medina, J. (2011). Sobre la práctica prospectiva. Una breve guía metodológica [On the prospective practice. A brief methodological guide]. Cuadernos de Administración, 14(21), 177-198.

Georghiou, L., Cassingena, J., Keenen, M., Miles, I. \& Popper, R. (2012). Manual de prospectiva tecnológica. Conceptos y práctica [Technological Prospective Manual. Concepts and Practice]. Flacso México. Retrieved from 
http://www.flacso.edu.mx/publicaciones/novedades/Manual-de-prospectiva-tecnologica-

Grant, R. (2006). Dirección Estratégica: Conceptos, Técnicas y Aplicaciones [Strategic Management: Concepts, Techniques and Applications]. $5^{a}$ edición. Madrid, España: S.L. Civitas Ediciones.

Godet, M. (1999). De la anticipación a la acción: Manual de prospectiva y estrategia [From anticipation to action: Prospective and Strategy Manual], México: Alfaomega.

Gutiérrez, K. (2007). El papel de la prospectiva en las instituciones universitarias desde una perspectiva conceptual [The role of foresight in the universities from a conceptual perspective], Informe de Investigaciones Educativas, 21, 79-91.

Guzmán, A., Malaver, M. \& Rivera, H. (2005). Análisis estructural. Técnica de la prospectiva [Structural analysis. Prospective technique].

Hernández, J. \& Rodriquez, L. (2011). Aplicación de los métodos prospectivos en la determinación de las competencias distintivas de la sucursal Cimex de Cienfuegos [Application of prospective methods in determining the distinctive competences of the Cimex branch of Cienfuegos]. Observatorio de la Economía Latinoamericana, (144). Retrieved from http://www.eumed.net/cursecon/ecolat/cu/2011/hsr.htm

Jiménez, M. (2009) Herramientas para el análisis prospectivo estratégico. Aplicaciones MICMAC [Tools for strategic prospective analysis. Applications MICMAC]. Estado de México: Hersa Ediciones.

Miklos, T, \& Tello, M. (2007). Planeación prospectiva y estratégica [Prospective and strategic planning]. In V Encuentro de estudios Prospectivos. Guadalajara, México.

Muñoz-Cano, J. M., Córdova, J. A., \& Priego, H. (2012). Dificultades y facilidades para el desarrollo de un proceso de innovación educativa con base en las Tecnologías de la Información y Comunicación (TIC) [Difficulties and facilities for the development of an educational innovation process based on Information and Communication Technologies (ICT)]. Formación universitaria, 5(1), 3-12.

Mojica, F. (2005). La construcción del futuro. Concepto y modelo de prospectiva estratégica, territorial y tecnológica [Future construction. Concept and model of strategic, territorial and technology foresight]. Santafé de Bogotá: Universidad Externado de Colombia.

Mojica, F. (2008). Forecasting y Prospectiva dos alternativas complementarias para adelantarnos al futuro [Forecasting and Prospective two complementary alternatives to anticipate the future]. Bogotá D.C. Retrieved from http://franciscomojica.com/articulos/adalfut.pdf.

Morin, E., \& Pakman, M. (1994). Introducción al pensamiento complejo [Introduction to complex thought]. Barcelona: Gedisa.

Noguera, A., \& Cubillos, F. (2007). La pertinencia de las facultades de Administración. Un estudio prospectivo al 2015 [The relevance of the Administrative Sciences Faculties. A prospective study in 2015]. Revista Universidad \& Empresa, 6(12), 194-224.

Ochoa, A., \& Orjuela, D. (2012). Análisis prospectivo de la Facultad de Administración del Colegio Mayor de Nuestra Señora del Rosario [Prospective analysis of the Management School of the Colegio Mayor de Nuestra Señora del Rosario]. Universidad del Rosario. Retrieved from http://repository.urosario.edu.co/handle/10336/2851?show=full.

Palomo, I., Veloso, C., \& Schmal, R. (2007). Sistema de Gestión de la Investigación en la Universidad de Talca [Management System Research at the University of Talca. Información Tecnológica, 18(1), 97-106.

Parra, C. (2004). Apuntes sobre la investigación formativa [Notes on the formative research. Education and educators. Educación y educadores, 7, 57-77.

Parra, P., Miklos, M., Herrera, A. \& Soto, R. (2007). Diseño de una metodología prospectiva aplicada en educación superior [Design of a prospective methodology applied in higher education. Edusfarm, Revista d'educació superior en Farmàcia, 1, 1-18.

Pereda, J. (1992). Prospectiva tecnológica: Una introducción a su metodología y a su aplicación en distintos países [Technological prospective: An Introduction to its methodology and its application in different countries]. Madrid, España: Fundación COTEC para la Innovación Tecnológica.

Portillo, R., \& Ortega, E. (2004). Análisis prospectivo de la Gestión de la Información y el Conocimiento [Prospective analysis of Information and Knowledge Management]. Quórum Académico, 1(2), 5-27.

Restrepo, B. (2006). Tendencias actuales en la educación superior: rumbos del mundo y rumbos del país [Current trends in higher education: world directions and country directions]. Revista Educación y Pedagogía. 18(46), 79-90.

Riffo, L. (1997). Métodos de investigación de prospectiva para la toma de decisiones [Prospective research methods for decisionmaking]. Instituto Latinoamericano y del Caribe de Planificación Económica y Social-Universidad del Valle.

Rodríguez, G. E. (2012). La prospectiva como disciplina sistemática: conceptos y técnicas [Prospective as a systematic discipline: concepts and techniquesv. Revista Universidad EAFIT. 27(82), 27-37.

Valderrama, J. O. (2005). Un modelo para la distribución racional de la actividad académica en una Universidad [A model for the rational distribution of academic activity at a university]. Información Tecnológica, 16(3), 3-14.

Villalobos, F. (2003). El papel de la acción prospectiva en la educación superior Venezolana: Riesgos y Desafíos para pensar la Universidad del mañana [The role of prospective action in the Venezuelan higher education: Risks and Challenges to think the University of tomorrow]. Investigación y Postgrado, 18(2), 97-115.

Zartha, J., \& Orozco, G. (2008). Estudio de prospectiva académica de la facultad de ingeniería agroindustrial de la Universidad Pontificia Bolivariana al año 2020 [Academic prospective study of faculty of agro-industrial engineering of the Universidad Pontificia Bolivariana towards 2020]. Facultad de Ciencias Agropecuarias, Universidad Pontificia Bolivariana, 9. 